\title{
A glargin és glulizin inzulinnal folytatott bázis-bolus kezelési rendszer egyéves eredményessége 2-es típusú cukorbetegségben
}

\author{
Elemzés a gyógyszerár-támogatás tükrében
}

\author{
Jermendy György dr. ${ }^{1}$ - Kovács Gábor dr. ${ }^{2}$ \\ ${ }^{1}$ Bajcsy-Zsilinszky Kórház és Rendelőintézet, Budapest \\ ${ }^{2}$ Medico-Pharmecon Kft., Budapest
}

\begin{abstract}
Bevezetés: Az inzulinanalógok bázis-bolus kezelési rendszerként 2-es típusú cukorbetegek körében történő alkalmazásának gyógyszerár-támogatási szabálya előírja, hogy a $100 \%$-os ártámogatás megtartása érdekében a $\mathrm{HbA}_{\mathrm{lc}}$-értéknek megadott időtartam-különbséggel mérve két ízben $<8,0 \%$-nak kell lennie, a humán inzulinnal folytatott kezelésrôl történő átállást követő 12 hónapon belül. Ha a cél teljesül, a kezelés finanszírozói szempontból eredményesnek minősül.
\end{abstract}

Célkitüzés. A jelen vizsgálat célja a bázis-bolus kezelésként alkalmazott glargin és glulizin inzulin finanszírozói szempontú eredményességének, valamint a glykaemiás kontroll fenntartásának a megítélése volt.

Módszer: A beavatkozással nem járó, l éves obszervációs vizsgálatban 2-es típusú diabeteses, korábban humán bázisbolus kezelésben részesülő, rossz glykaemiás kontrollú $\left(\mathrm{HbA}_{1 \mathrm{c}}>9,0 \%\right)$ felnôttek vettek részt. A fó értékelési végpont a finanszírozói szempontú eredményesség elérése, valamint a hatodik hónapra finanszírozói célértéken $\left(\mathrm{HbA}_{\mathrm{lc}}\right.$ $<8,0 \%)$ lévők célértékmegtartási aránya volt a vizsgálat végén. Biztonságossági paraméterként a hypoglykaemiás eseményeket regisztráltuk.

Eredmények: A bevont 557 betegből a hatásossági elemzésben 287 beteg adatait lehetett értékelni, közülük 169 $(58,9 \%)$ érte el a finanszírozási szabályok szerint elóírt glykaemiás kontrollt. A hatodik hónapban az elö́rt $\mathrm{HbA}_{1 c^{-}}$ célértékkel $(<8,0 \%)$ rendelkező 167 beteg közül $152(91 \%)$ maradt célértéken a vizsgálati periódus további hat hónapjában is. Nem súlyos hypoglykaemiás esemény 1221 alkalommal, súlyos hypoglykaemiás esemény 6 alkalommal fordult elö.

Következtetések: A glargin és glulizin inzulinnal újonnan megkezdett bázis-bolus kezelési rendszer a 2-es típusú cukorbetegségben szenvedő betegek több mint felében biztosította azt az eredményességet, amelyet a finanszírozási szabályok a folyamatos $100 \%$-os támogatás feltételéül jelölnek meg. Az eredmények azonban azt is feltárták, hogy a betegek figyelemre méltó részében az anyagcsere-állapot ellenőrzése a $\mathrm{HbA}_{1 \mathrm{c}}$-szint mérésével nem a finanszírozási szabályoknak megfelelően történt.

Orv Hetil. 2018; 159(50): 2122-2128.

Kulcsszavak: 2-es típusú cukorbetegség, bázis-bolus kezelési rendszer, inzulinanalógok, glargin inzulin, glulizin inzulin, gyógyszerár-támogatás

\section{Effectiveness of one-year insulin glargine and insulin glulisine basal-bolus treatment in people with type 2 diabetes}

\section{An analysis from drug reimbursement perspective}

Introduction: Being entitled for no patient co-payment, the Hungarian reimbursement condition of analogue insulins as part of basal-bolus treatment in type 2 diabetes mellitus (T2DM) requires that two $\mathrm{HbA}_{\mathrm{lc}}$ levels should achieve $<8.0 \%$ target value within 12 months (measured two months apart) after switching from treatment with human insulins. Achieving this target, the treatment should be considered effective from drug reimbursement perspective. 
Aim: The aims of the study were to investigate the effectiveness of insulin glargine + insulin glulisine basal-bolus regimen from the payer's perspective and to investigate the ability to maintain the achieved glycaemic control in previously uncontrolled T2DM patients $\left(\mathrm{HbA}_{\mathrm{lc}}>9.0 \%\right)$.

Method: This one-year, non-interventional study included patients with T2DM inadequately controlled $\left(\mathrm{HbA}_{\mathrm{lc}}\right.$ $>9.0 \%$ ) on previous human basal-bolus treatment. The main outcomes were the proportion of patients who achieved the adequate glycaemic control (defined by the reimbursement rules) and the proportion of patients who achieved reimbursement rules defined $\mathrm{HbA}_{1 \mathrm{c}}<8.0 \%$ target value by the 6 months after switch and could maintain this glycaemic control for upcoming further 6 months. As safety outcome, the hypoglycaemic events were recorded.

Results: Out of the 557 patients enrolled, 287 had available data to be included in the efficacy analysis. Out of the 287 efficacy analysis patients, $169(58.9 \%)$ achieved the reimbursement rules defined glycaemic control. At 6 months, 167 patients had $\mathrm{HbA}_{\mathrm{lc}}$ value $<8.0 \%$ and $152(91.0 \%)$ remained in this target range until the end of the 12 -month observational period. Overall, 1221 non-severe and 6 severe hypoglycaemic events were reported.

Conclusions: More than half of the patients with T2DM who were newly switched to insulin glargine + glulisine basalbolus treatment could achieve the reimbursement rule criteria requiring for prescription of the analogue insulins with no co-payment beyond 1 year of treatment in Hungary. However, the results revealed that glycaemic control assessment with $\mathrm{HbA}_{\mathrm{lc}}$ measurements had not met the reimbursement requirements in a significant part of patients.

Keywords: diabetes mellitus type 2, basal-bolus insulin treatment regimen, insulin analogues, insulin glargine, insulin glulisine, drug reimbursement

Jermendy Gy, Kovács G. [Effectiveness of one-year insulin glargine and insulin glulisine basal-bolus treatment in people with type 2 diabetes. An analysis from drug reimbursement perspective]. Orv Hetil. 2018; 159(50): 21222128.

(Beérkezett: 2018. június 8.; elfogadva: 2018. július 11.)

\section{Rövidítések}

$\mathrm{ADA}=($ American Diabetes Association $)$ Amerikai Diabetes Társaság; $\mathrm{BMI}=($ body mass index $)$ testtömegindex; EASD = (European Association for the Study of Diabetes) Európai Diabetes Társaság; $\mathrm{HbA}_{1 \mathrm{c}}=$ hemoglobin $\mathrm{A}_{1 \mathrm{c}} ; \mathrm{MDT}=$ Magyar Diabetes Társaság; $\mathrm{NE}=$ nemzetközi egység; $\mathrm{NPH}=$ (neutral protamine Hagedorn) neutrális protamin Hagedorn szerint készítve; $\mathrm{OAD}=$ orális antidiabetikum; OEP = Országos Egészségbiztosítási Pénztár $=$ Nemzeti Egészségbiztosítási Alapkezelő; SD = (standard deviation) standard szórás; T2DM $=($ type 2 diabetes mellitus $) 2$-es típusú cukorbetegség

A 2-es típusú cukorbetegség kezelésében - az újabb, innovatív készítmények megjelenése után is - az inzulinterápia régóta elfogadott terápiás opciót jelent; ez a tény a hazai helyzetre is jellemző [1-4]. Alkalmazása indokolt újonnan felismert diabetes esetén akkor, ha a manifesztációt markáns klinikai jelek kísérik, és a metabolikus dekompenzáció laboratóriumi jelei (magas $\mathrm{HbA}_{\mathrm{lc}}$, jelentősen emelkedett vércukor, acetonuria) észlelhetók. A 2-es típusú diabetes hosszú kórlefolyása során azonban inzulinterápia akkor is választható, ha a szokásos kezelési lépések (életmód-terápia, metforminmonoterápia) nem vezetnek eredményre, $s$ a kezelésben tovább kell építkezni a jó glykaemiás kontroll elérése érdekében. A kettős vagy olykor hármas kombinációs kezelés egyik lehetőségét az OAD + bázisinzulin alkalmazása jelenti. A kezelés intenzifikálásában azonban gyakran tovább kell lépni, s ilyenkor az egyik választási lehetőséget a bázis-bolus inzulinkezelési rendszer felépítése jelenti $[5,6]$. Bázis-bo- lus kezelési rendszerben alkalmazhatók a humán inzulinok is, de az inzulinanalógok előnyösebbek, mert azok alkalmazása a betegek számára nemcsak életmódbeli könnyebbséget jelentenek, hanem gyakran jobb glykaemiás kontrollt és hypoglykaemiakockázat-csökkenést is biztosíthatnak. Bár 2-es típusú diabetes mellitusban az inzulin alkalmazása kétségkívül hatékony kezelési módot jelent, sok cukorbeteg esetében az inzulinkezelés bevezetése gyakran késik [7].

Bár az ORIGIN-vizsgálat bizonyította, hogy OAD nélkül vagy egyetlen $\mathrm{OAD}$ adásával kiegészített, korai stádiumban megkezdett, glargin inzulinnal folytatott kezelés akár öt évig is képes fenntartani a megfelelő glykaemiás kontrollt [8], a valós klinikai gyakorlatban még az inzulinkezelés időben történő megkezdése is komoly kihívást jelent [9]. Mind a hosszú, mind a rövid hatású inzulinanalógokról igazolták, hogy klinikai vonatkozásban előnyösebbek a megfelelő humán változatokhoz képest: alkalmazásuk során csökken a hypoglykaemia kockázata, jobb lehet a postprandialis vércukorkontroll, a terápia kivitelezése a betegek számára könnyebbséget jelent, sôt cardiovascularis előnyökről is beszámoltak [10-12]. A $100 \mathrm{E} / \mathrm{ml}$ kiszerelésú glargin inzulin elnyújtott, egyenletes hatásgörbéje napi egyszeri alkalmazást tesz lehetôvé, az NPH-inzulinokkal szemben azokhoz hasonló anyagcsere-kontrollt biztosít [13] kevesebb hypoglykaemiás eseménnyel [14-17]. A glulizin inzulin a rövid hatástartamú inzulinanalógok között hazánkban harmadikként került forgalomba, jellegzetességei lényegében nem különböznek az elérhető másik két, rövid 
hatású inzulinanalógtól (lizpro inzulin, aszpart inzulin). Alkalmazásuk során a humán gyors hatású inzulinhoz képest markánsabb postprandialis vércukorkontroll biztosítható, de a hypoglykaemiás események csökkenése is remélhető.

Hazánkban az inzulinanalógok teljes (100\%-os) ártámogatással való felírhatósága, valamint a felírás egy éven túli folytatása 2-es típusú cukorbetegségben részben a terápia megkezdését követően elért $\mathrm{HbA}_{\mathrm{lc}}$-értéktől függ. A váltás egyik finanszírozási előfeltétele, hogy a megelőzően legalább 3 hónapig folytatott humán intenzifikált inzulinkezelés mellett a glykaemiás kontroll elmaradjon a hatóság által definiált határértéktől $\left(\mathrm{HbA}_{\mathrm{lc}}\right.$ $\geq 8,0 \%)$. Az inzulinanalóggal megkezdett bázis-bolus kezelés 100\%-os finanszírozású fenntartásának feltétele azonban az, hogy a $\mathrm{HbA}_{\mathrm{lc}}$-érték a váltást követően $8,0 \%$ (finanszírozói célérték) alá csökkenjen. A 100\%-os támogatást a finanszírozó akkor tartja fenn, ha a váltást követő 12 hónapos terápiás periódus alatt legalább két, minimum 2 hónapos különbséggel mért $\mathrm{HbA}_{1 \mathrm{c}}$-érték 8,0\% alatti - vagyis a beteg eléri a finanszírozói szempontú eredményességet [18]. Vannak olyan betegek, akik az inzulinanalóggal folytatott bázis-bolus kezelési rendszerrel rövid távon elérik ugyan a $\mathrm{HbA}_{\mathrm{lc}} 8,0 \%$ alatti (finanszírozói) célértékét, de számos okból (például edukációs hiányosságok, adherenciaproblémák, a diétás fegyelem lazulása miatt) hosszabb távon nem tudják stabilizálni a kezdeti jó eredményeket. A cukorbeteg-gondozás során elég gyakran találkozunk olyan betegekkel, akik inzulinanalóg mellett nem tudják elérni vagy fenntartani a $\mathrm{HbA}_{\mathrm{lc}}$-célértéket, kiesnek a legmagasabb támogatási kategóriából, ezért vagy alacsonyabb támogatással kapják az inzulinanalógokat, vagy kezelésük „visszalép” a humán inzulinnal folytatott terápiára.

$\mathrm{Az}$ inzulinkezelés biztonságosságát az anyagcserekontroll szempontjából a hypoglykaemiás és különösen a súlyos hypoglykaemiás események gyakoriságának regisztrálásával szokás nyomon követi. A finanszírozási rendszer súlyos vagy ismétlődő hypoglykaemia esetében a $\mathrm{HbA}_{\mathrm{lc}}$-értéktől függetlenül lehetőséget biztosít az inzulinanalóggal folytatott terápia megkezdésére és fenntartására [18].

Bázis-bolus inzulinkezelési rendszer mellett 2-es típusú diabetesben kevés obszervációs vizsgálatot végeztek hazánkban [19]. A jelen vizsgálat célja a glargin inzulinnal és glulizin inzulinnal folytatott bázis-bolus kezelési rendszer finanszírozói szempontú eredményességének, valamint a glykaemiás kontroll fenntartásának a megítélése volt 2 -es típusú diabetes mellitusban szenvedő olyan betegek körében, akiknél az inzulinanalóggal folytatott terápiát újonnan indították.

\section{Módszer}

A prospektív, beavatkozással nem járó vizsgálatot 18 . életévüket betöltött, 2 -es típusú diabetes mellitusban szenvedő felnőtt betegek bevonásával végeztük. A bete- gek antidiabetikus kezelése a beválasztáskor legfeljebb 4 hete tartott glargin inzulin $\left(100 \mathrm{E} / \mathrm{ml}\left[\right.\right.$ Lantus $\left.\left.^{\circledR}\right]\right)$ és glulizin inzulin $\left(\right.$ Apidra $\left.^{\circledR}\right)$ kombinációjával megvalósított bázis-bolus rendszerú terápiával. Az inzulinanalóggal végzett bázis-bolus kezelés indikációjául szolgáló $\mathrm{HbA}_{\mathrm{lc}^{-}}$ érték legalább 9,0\% volt. Az inzulin mellett alkalmazott OAD (a leggyakrabban metformin, kisebb részben szulfanilurea) adása nem volt kizáró ok. A beválasztási vizitet követő 1 évben további 3 utánkövetési vizitre és ezzel együtt adatgyüjtésre került sor. Kötelező kivizsgálás vagy kezelés nem volt előírva - a vizsgálat megfigyeléses jellegéből adódóan. A beválasztáskor regisztráltuk a vizsgálat megkezdése előtti 3 hónapban észlelt hypoglykaemiás események számát.

Rögzítésre kerültek: a legfontosabb kórelőzményi és klinikai adatok (életkor a beválasztáskor, a diabetes felismerésekor, az inzulinterápia megkezdésekor; inzulinkezelési előzmények, BMI), a rendelkezésre álló, az adatrögzítés előtti legutolsó $\mathrm{HbA}_{\mathrm{lc}}{ }^{-}$, éhomi és postprandialis vércukorértékek (attól függetlenül, hogy azokat laboratóriumban mérték, vagy a beteg maga mérte), az inzulinok napi dózisa, valamint a hypoglykaemiás események száma és jellege (nem súlyos, súlyos).

Hatásossági és biztonságossági elemzést végeztünk. A hatásossági elemzésben csak azokat a betegeket vettük figyelembe, akiknél rendelkezésre álltak az egyéves követés adatai, valamint akik a beválasztást követően legalább további három $\mathrm{HbA}_{\mathrm{lc}}$-eredménnyel rendelkeztek, és a $\mathrm{HbA}_{1 \mathrm{c}}$-mérések között legalább két hónap telt el (az OEP finanszírozási előírásainak megfelelően [18]). A biztonságossági elemzésben a vizsgálatba bevont valamennyi beteg szerepelt.

A vizsgálat elsődleges végpontja kettős volt: (1) azon betegek aránya, akiknél a glargin + glulizin inzulinnal folytatott bázis-bolus kezelési rendszer elkezdése utáni egy évben a legalább három, egymástól minimálisan két hónap időközzel mért $\mathrm{HbA}_{\mathrm{lc}}$-értékek közül legalább kettő 8,0\% alatti volt (finanszírozói szempontú eredményesség); (2) a vizsgálat hatodik hónapjára finanszírozói $\mathrm{HbA}_{1 \mathrm{c}}$-célértékre $(<8,0 \%)$ került betegek közül azoknak az aránya, akik az első év végére is a céltartományban maradtak. Másodlagos végpontként a glykaemiás értékek, az inzulindózisok és a BMI változását értékeltük. Biztonságossági szempontból a hypoglykaemiás események előfordulási gyakoriságát analizáltuk.

A hypoglykaemiaeseményeket vércukor-önellenőrzéssel megerősített érték esetén vettük figyelembe. Enyhe (nem súlyos) hypoglykaemiaeseménynek a vércukor $\leq 3,9$ mmol/l értéket minősítettük akkor, ha a beteg önmaga korrigálni tudta a helyzetet, attól függetlenül, hogy klinikai tünet kísérte-e az állapotot vagy sem. Súlyos hypoglykaemiaként értékeltük azt a rosszullétet, amikor a vércukor $\leq 3,9 \mathrm{mmol} / 1$ értékü volt, $\mathrm{s}$ a klinikai tünetek elhárításához külső segítségre volt szükség.

A folytonos változók leírására átlagot és szórást $(\mathrm{SD})$, a kategorikus változók jellemzésére esetszámot és előfordulási gyakoriságot $(\mathrm{n}, \%)$ használtunk. A folytonos 
1. táblázat $\mid$ A hatásossági vizsgálatban szereplő betegek $(\mathrm{n}=287)$ fontosabb klinikai és laboratóriumi adatai

\begin{tabular}{lc}
\hline Mért változók & Átlag \pm SD \\
\hline Életkor & $61,0 \pm 9,5$ \\
\hline a beválasztáskor (év) & $48,6 \pm 9,0$ \\
a diabetes mellitus diagnosztizálásakor (év) & $55,1 \pm 9,4$ \\
az inzulinhasználat kezdetekor (év) & \\
\hline Inzulinkezelési elózmények & $29,7 \pm 17,7$ \\
\hline a humán bázisinzulin napi dózisa (NE) & $46,4 \pm 19,7$ \\
a humán prandialis inzulin napi dózisa (NE) & $9,7 \pm 0,9$ \\
\hline Kiindulási értékek & $10,7 \pm 3,2$ \\
\hline HbA ${ }_{1 \mathrm{c}}$ (\%) & $13,4 \pm 3,2$ \\
éhomi vércukor (mmol/1) & $33,3 \pm 6,6$ \\
\hline postprandialis vércukor (mmol/l) & $35,0 \pm 16,3$ \\
BMI (kg/m²) & $38,6 \pm 16,7$ \\
\hline Az inzulinanalógok dózisa a terápiaváltáskor & \\
\hline a glargin inzulin dózisa (NE) & \\
a glulizin inzulin dózisa (NE) & \\
\hline
\end{tabular}

$\mathrm{BMI}=$ testtömegindex $\mathrm{HbA}_{\mathrm{lc}}=$ hemoglobin $\mathrm{A}_{\mathrm{lc}} ; \mathrm{NE}=$ nemzetközi egység; $\mathrm{SD}=$ standard szórás

változók időbeli változásának összehasonlítására páros t-próbát, a kategorikus változók megoszlásának összehasonlítására egymintás binomiális tesztet alkalmaztunk. A normalitást a $\mathrm{Q}-\mathrm{Q}$ plotok módszerével ellenóriztük. A p $<0,05$ értéket tekintettük statisztikailag szignifikánsnak. A statisztikai értékeléshez SPSS 19.0.0 programot (IBM, Armonk, NY, Amerikai Egyesült Államok) alkalmaztuk.

A vizsgálatot a Gyógyszerészeti és Egészségügyi Minőség- és Szervezetfejlesztési Intézet, Országos Gyógyszerészeti Intézet engedélyezte (ügyszám: OGYI/20539$1 / 2014)$.

\section{Eredmények}

\section{Kiindulási adatok}

A vizsgálatba bevont 557 beteg közül 287-nek (51,5\%) voltak megfelelőek az adatai a hatásossági elemzésre.

Az értékelt betegcsoport $(\mathrm{n}=287)$ átlagos életkora 61 év, a diabetestartam 12 év, az inzulinterápia tartama mintegy 6 év volt; a betegek a BMI átlagértéke alapján elhízottak voltak. Beválasztáskor a laboratóriumi adatok rossz glykaemiás kontrollt tükröztek (1. táblázat). A nem értékelt (kiesett) betegek életkor-paraméterei (életkor a beválasztáskor, a diabetes kezdetekor, az inzulinterápia megkezdésekor) átlag 2 évvel alacsonyabbak voltak, de a beválasztási glykaemiás adataik, BMI-értékük és a kezdő inzulindózisuk terén nem volt értékelhető különbség az értékelt és a kiesett betegek csoportja között.

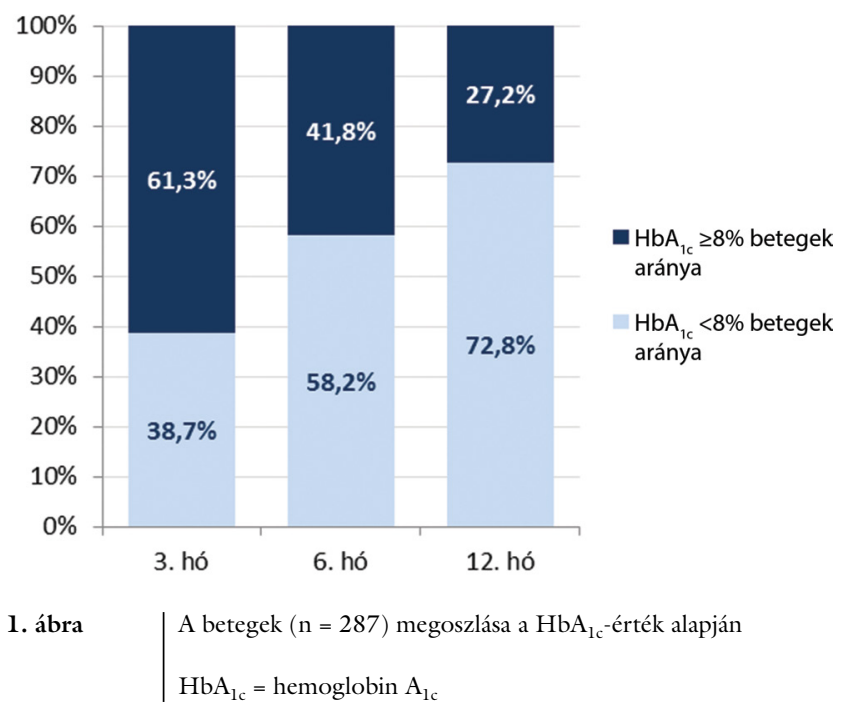

\section{Hatásossági vizsgálatok}

\section{A glykaemiás kontroll alakulása}

A finanszírozói szempontú $\mathrm{HbA}_{\mathrm{lc}}$-célértéket $(<8,0 \%)$ az adott időpontban elérők aránya fokozatosan nőtt, a harmadik hónapban a betegek $(\mathrm{n}=287) 38,7 \%$-a, a vizsgálat végén $72,8 \%$-uk érte el a célértéket (1. ábra).

A betegcsoportban $(\mathrm{n}=287)$ finanszírozói szempontból $169(58,9 \%)$ beteg kezelése volt eredményes - ők azok a betegek, akik jogosultak a 100\%-os ártámogatásra a kezelés első éve után is, miután a rendeletben előírt gyakorisággal rendelkeztek ismételten $<8,0 \%$ alatti $\mathrm{HbA}_{1 \mathrm{c}}$-értékkel.

A hatodik hónapban a finanszírozói szempontú $\mathrm{HbA}_{1 \mathrm{c}}{ }^{-}$ célértéken (<8,0\%) lévő 167 beteg közül 152 (91\%) maradt célértéken a vizsgálat további hat hónapjában is.

\section{A glykaemiás értékek és a BMI változása}

A $\mathrm{HbA}_{\mathrm{lc}^{-}}$, az éhomi és postprandialis vércukorérték folyamatosan csökkent a vizsgálat ideje alatt. A legnagyobb mértékű csökkenés mindhárom változó esetében a bevonást követő első három hónapban következett be: a kiindulási helyzethez viszonyított abszolút változások sorrendben $-1,4 \pm 0,9 \%,-2,6 \pm 2,9 \mathrm{mmol} / 1$ és $-3,7 \pm 3,4$ $\mathrm{mmol} / 1$ voltak (mindhárom esetben $\mathrm{p}<0,001$ ). A vizsgálat végére a $\mathrm{HbA}_{\mathrm{lc}}$-érték 2,0\%-kal, 9,7\%-ról 7,7\%-ra, az éhomi vércukor $3,3 \mathrm{mmol} / 1$ értékkel 10,7 mmol/1-ról 7,4 mmol/l-re, a postprandialis vércukor 4,6 mmol/1 értékkel 13,4 mmol/1-ról 8,8 mmol/l-re csökkent (valamennyi változó esetében $\mathrm{p}<0,001)$. A három glykaemiás érték változását a 2. ábra szemlélteti.

A BMI statisztikailag szignifikáns, de klinikai szempontból nem jelentős mértékben csökkent a vizsgálat kezdete $\left(33,3 \pm 6,6 \mathrm{~kg} / \mathrm{m}^{2}\right)$ és vége között $(32,8 \pm 6,2$ $\left.\mathrm{kg} / \mathrm{m}^{2}, \mathrm{p}<0,001\right)$.

\section{Az inzulindózisok alakulása}

A glargin és a glulizin inzulin átlagos dózisa minden viziten statisztikailag szignifikáns mértékben nagyobb 


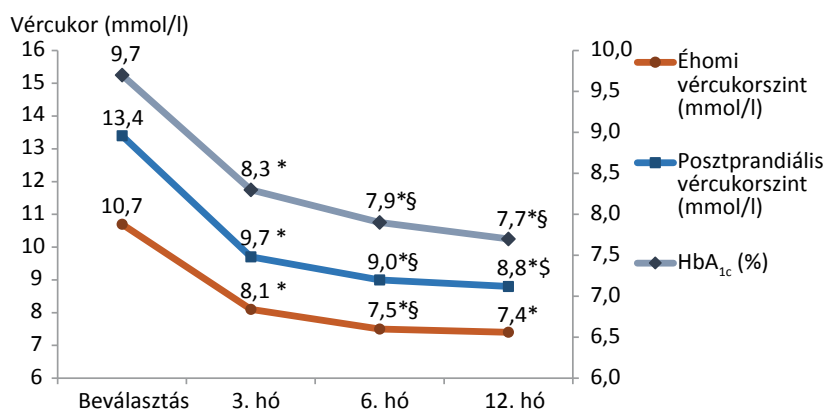

2. ábra

$$
\begin{aligned}
& \text { A glykaemiás átlagértékek alakulása a vizsgálat időtartama alatt } \\
& { }^{*} \mathrm{p}<0,001 \text { versus kiindulási érték; }{ }^{\S} \mathrm{p}<0,001 \text { versus megelőző ido”- } \\
& \text { pontban mért érték; }{ }^{\$} \mathrm{p}<0,05 \text { versus megelőző időpontban mért } \\
& \text { érték } \\
& \mathrm{Hb}_{\mathrm{lc}}=\text { hemoglobin } \mathrm{A}_{\mathrm{lc}}
\end{aligned}
$$

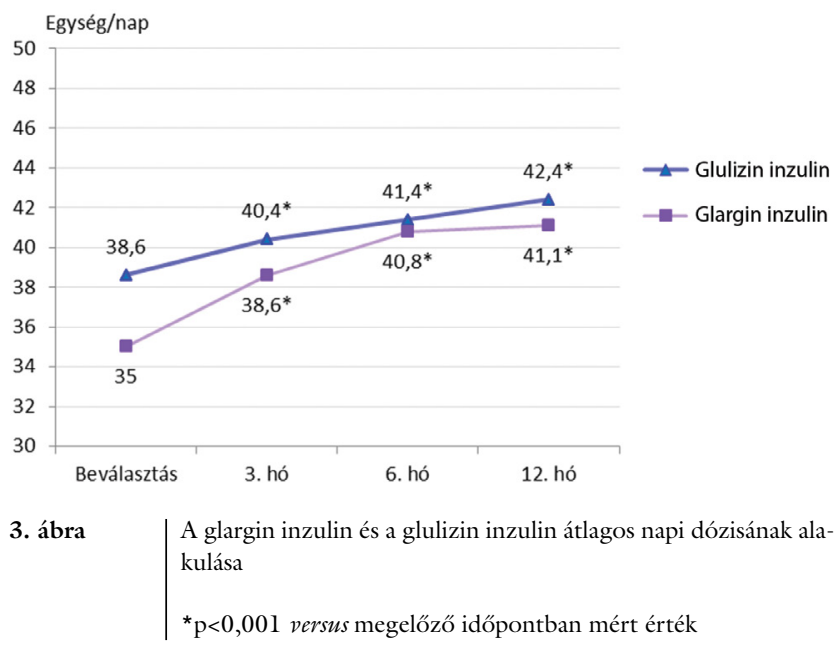

volt, mint az előző viziten. A kiindulási értékkel összehasonlítva a vizsgálat végéig a glargin inzulin dózisát relatíve nagyobb mértékben (körülbelül 17\%) növelték, mint a glulizin inzulinét (körülbelül 10\%) (3. ábra).

\section{Biztonságossági vizsgálat}

\section{A hypoglykaemiás események alakulása}

A bevonást megelőző 3 hónapban 198 betegben összesen 856 nem súlyos hypoglykaemiás eseményt regisztráltak. A vizsgálat teljes időtartama alatt összesen 1221 nem súlyos, vércukorméréssel megerősített (vércukor $\leq 3,9 \mathrm{mmol} / \mathrm{l}$ ) átmeneti hypoglykaemiás eseményt regisztráltak. A beválasztás és a 3. hónap között 155 betegben 465 esemény, a 3. és a 6 . hónap között 149 betegben 408 esemény, míg a 6 . és a 12. hónap közötti hat hónapban már csak 131 betegben 348 esemény fordult elő.

A vizsgálat ideje alatt 6 súlyos hypoglykaemiás esemény fordult elő: az első három hónapban 2 betegben, a második három hónapban 1 , míg az utolsó hat hónapban 3 betegben 1-1 esemény.

\section{Megbeszélés}

Obszervációs jellegú vizsgálatunk eredménye szerint a 2 -es típusú diabetesben szenvedő, bázis-bolus inzulinkezelési rendszeren lévő betegek közel 60\%-a jogosult a glargin + glulizin inzulinokkal indított terápiaváltás után egy évvel az inzulinanalógok 100\%-os támogatással történő folytatólagos felírására. Esetükben teljesült ugyanis az az előírás, amely szerint a $100 \%$-os támogatás változatlan megtartásához megfelelő glykaemiás válasz dokumentálása (egy éven belül, legalább 2 hónap különbséggel, 2 alkalommal meghatározott $8,0 \%$ alatti $\mathrm{HbA}_{1 \mathrm{c}}$-érték megléte) szükséges.

Az inzulinanalógok számos vonatkozásban felülmúlják a megfelelő humán inzulinokat. Nem véletlen, hogy az l-es típusú diabetesben szenvedők esetében az inzulinanalógokkal történő fenntartó kezelést nem szabályozza semmilyen körülmény (a $\mathrm{HbA}_{\mathrm{lc}}$-értéktől függetlenül 100\%-os támogatással rendelhetôk). Az előnyökből tulajdonképpen szakmai szempontok alapján nem volna szabad kizárni a 2-es típusú diabetesben szenvedőket sem. Ugyanakkor érthető az a finanszírozói álláspont, amely inkább ösztönözni és jutalmazni kívánja a jó glykaemiás kontroll elérését a betegek döntő hányadát kitevő 2-es típusú cukorbetegek körében, a támogatási keret véges jellege folytán. Mindezek nyomán azonban az inzulinanalógok használata hazánkban erősen háttérbe szorul, ami különösen élesen tetten érthető, ha nemzetközi adatokat is tekintünk. Az inzulinanalógok penetrációja (a teljes inzulinpiacon belüli felhasználási részaránya) terén Európa országai között a 2013. második negyedév adatai alapján Magyarország 39,7\%-kal az utolsó helyen szerepelt [20]. Nem valószínú, hogy azóta döntő változás következett volna be.

Bármely antidiabetikus kezelés elsődleges célja a hyperglykaemia mérséklése, az adott betegnél a megfelelő glykaemiás kontroll elérése. Az ADA-EASD szakmai állásfoglalása már évek óta a $\mathrm{HbA}_{\mathrm{lc}}<7,0 \%$ elérését hangsúlyozza a kezelési célértéknél [6]. Az utóbbi években azonban az egyetlen értékhez kötött cél helyett a kezelési céltartomány fogalma került előtérbe, az MDT szakmai irányelve már 2014-ben bevezette ezt a fogalmat. Nyilvánvalóvá vált ugyanis, hogy a kezelés megválasztásakor számos körülményt mérlegre kell tenni, s a kezelési cél kijelölésekor lehetünk szigorúbbak (fiatal, szövődménymentes cukorbetegek esetében), de olykor megengedőbbek is (idősebb, várhatóan rövidebb élettartamú, társbetegségekben is szenvedő cukorbetegek esetében). A HbA $\mathrm{lc}_{\mathrm{c}}$-érték kezelési céltartománya általában $6,0-8,0 \%$ közötti, kivételes esetben akár $8,5 \%$ is lehet. Helyesen az individualizált antidiabetikus kezeléshez egyénre szabott kezelési cél tartozik [5].

A szakmai alapokon nyugvó kezelési cél nem azonosítható a finanszírozó által bevezetett, a támogatás folytatólagos $100 \%$-os mértékének feltételéül szabott $\mathrm{HbA}_{\mathrm{lc}^{-}}$ célértékkel $(<8,0 \%)$ [18]. A rendelet bevezetése évekkel ezelőtt a szakma (MDT, szakmai kollégium) és a hatóság 
képviselőinek megbeszélése nyomán lépett életbe. Bár súlyos hypoglykaemia előfordulásakor a $\mathrm{HbA}_{\mathrm{lc}}$-értéktől függetlenül is jogosult a beteg a 100\%-os támogatásra, a cukorbeteg-gondozás során számos nehézség jelentkezik a rendelet betartásával kapcsolatban. Ezt visszatükrözte jelenlegi felmérésünk is.

A vizsgálatunkba bevont betegek csupán alig több mint felében (51,7\%-ukban) tudtunk hatásossági elemzést végezni, miután csak ezeknél a betegeknél álltak rendelkezésre azok a laboratóriumi adatok $\left(\mathrm{HbA}_{\mathrm{lc}}\right.$-értékek), amelyeknek a kellő számú és kellő időközökben végzett meghatározását a finanszírozási szabályok [18] elóírják a támogatás mértékének meghatározásakor. Nem vitás, hogy az időszakos $\mathrm{HbA}_{1 \mathrm{c}}$-érték meghatározása hozzátartozik a cukorbeteg-gondozáshoz. Ugyanakkor adatunk nyomán érdemes volna a hatóságnak mérlegelnie, hogy nem lenne-e időszerü a rendeletben megfogalmazottak felülvizsgálata.

Noha a $\mathrm{HbA}_{\mathrm{lc}}$-érték csökkenése a megfigyelés végére markáns volt (az átlagérték 9,7\%-ról 7,7\%-ra csökkent), a glykaemiás kontrollnak a finanszírozási szabályok szerinti javulása ( 2 érték <8,0\%) csak a betegek 58,9\%-ában teljesült. Ez arra utal, hogy a 2-es típusú cukorbetegségben szenvedők jelentős hányadában bázis-bolus rendszerü inzulinanalógokkal eredményesek lehetünk, de szép számmal vannak olyanok is, akiknél a terápia felülvizsgálata indokolt. Ma már 2-es típusú diabetesben az inzulinterápia intenzifikálásának alternatívája is a betegek rendelkezésére áll, illetve inzulin mellett választhatók olyan orális antidiabetikumok is, amelyek kombinációs alkalmazása nemcsak a glykaemiás kontroll javulását, hanem a testsúly mérséklését is elősegíti.

Bázis-bolus kezelési rendszer esetén a bázis és a prandialis inzulinok egymáshoz viszonyított aránya általában $50 \%$ szokott lenni, bár 2-es típusú diabetesben az arány magasabb is lehet. Vizsgálatunk során a dózisokat a kezelőorvosok emelték, az arány azonban érdemben nem változott. Bár inzulinkezelés mellett a testsúly általában nőni szokott, ezt a vizsgálatban nem figyeltük meg. Ennek oka lehet az, hogy az új kezelési rendszerrel összefüggésben a diétás előírások módosultak (napi háromszori étkezés elegendő, a köztes kis étkezések elhagyhatók). Vizsgálatunk obszervációs jellegéből adódóan azonban a megfigyelt változások pontos okára vonatkozóan adatokat nem nyerhettünk.

A hypoglykaemia számszerü alakulását leíró jelleggel közöltük. Az irodalomban dokumentált, hogy mind a gyors hatású inzulinanalógok, mind a glargin inzulin alkalmazása csökkenti a hypoglykaemia kockázatát a megfelelő humán inzulinokhoz viszonyítva [17]. Eredményeink ezt megerősítették, mivel a bevonást követő első három hónapban alig több mint feleannyi nem súlyos hypoglykaemiát regisztráltunk, és az eseményszám a követés későbbi periódusában tovább csökkent.

Napjaink jellegzetessége, hogy a való életből vett, obszervációs jellegű vizsgálatok iránti érdeklődés egyre nő. A randomizált, kontrollált klinikai vizsgálatok természe- tesen nagyon fontosak, azok képezik a tényeken alapuló orvoslás alapjait. Ezeknek a vizsgálatoknak is vannak azonban sajátosságaik, jellegzetességeik, amelyek miatt a szakmai közvélemény és a hatóságok előszeretettel nyugtázzák az obszervációs vizsgálatok eredményeit, különösen akkor, ha azok megerősítik a randomizált tanulmányok eredményeit. Jelenlegi obszervációs vizsgálatunk ilyennek tekinthető az inzulinanalógokkal (glargin és glulizin inzulinnal) folytatott kezelés terén 2-es típusú diabetesben.

Az obszervációs jellegú, beavatkozással nem járó adatgyüjtésünk értékelhetőségének legfontosabb korlátja, hogy az egészségügyi rendeletben elöírt $\mathrm{HbA}_{\mathrm{lc}}$-ellenőrzést csak a bevont betegek alig több mint felénél végezték el megfelelően, így a hatásossági elemzésbe a beválasztott betegek jelentős része nem kerülhetett be. A limitációk között meg kell említeni, hogy az esetleg társuló OAD-kezelés megoszlásáról, a dózisok változásáról nem rendelkeztünk adatokkal, így ezeknek a gyógyszereknek az anyagcserekontrollra vagy a testtömegindexre kifejtett módosító hatását nem tudtuk felmérni.

Összefoglalva megállapítható, hogy a rossz glykaemiás kontrollú, humán inzulinnal folytatott bázis-bolus rendszerű inzulinkezelésben részesülő 2-es típusú cukorbetegek glykaemiás kontrollja jelentősen javult az inzulinanalóggal (glargin + glulizin inzulinnal) megvalósított bázis-bolus rendszerű kezelésre való váltás utáni 12 hónapban. A finanszírozási rendeletek elöírása szerint ellenőrzött betegek több mint fele teljesítette azt a feltételt, amelynek alapján az inzulinanalóggal folytatott bázis-bolus rendszerű kezelés változatlanul 100\%-os támogatással rendelhető. Kedvező eredmény, hogy az emelkedő inzulindózisok ellenére az átlagos testtömegindex nem növekedett, és a váltás után 6 hónappal célértékre kezelt betegek döntő része meg tudta tartani a kedvező anyagcsere-állapotot. Vizsgálatunk eredménye megerősíti az MDT 2017. évi szakmai irányelvében leírtakat [5], amely szerint 2-es típusú diabetesben az első választandó inzulinkészítményként az inzulinanalógok preferálandók a humán inzulinokkal szemben.

Anyagi támogatás: A vizsgálat a Sanofi-Aventis Zrt. anyagi támogatásával zajlott.

Szerzői munkamegosztás: J. Gy.: A hipotézis kidolgozása, a vizsgálat eredményeinek összegzése, elemzése, a kézirat összeállítása, véglegesítése. K. G.: A vizsgálat eredményeinek összegzése, statisztikai elemzés, a kézirat első változatának szövegezése. A cikk végleges változatát mindkét szerző elolvasta és jóváhagyta.

Érdekeltségek: J. Gy. a Sanofi-Aventis Zrt.-től díjazásban részesült a jelen vizsgálat szakmai előkészítéséért, abban vezető vizsgálóként való részvételért és a jelen kézirat véglegesítéséért. K. G. a Sanofi-Aventis Zrt.-tôl díjazásban részesült a jelen vizsgálat szakmai előkészítéséért, a 
statisztikai kiértékelésben és a jelen kézirat elkészítésében való közremúködésért. A szerzőknek egyéb szempontból nincsenek érdekeltségeik.

\section{Köszönetnyilvánítás}

A vizsgálatban részt vevő orvosok: Ambrusics Anna dr., Bandur Szilvia dr., Barczi Erika dr., Báthori Mária dr., Bilekov Éva dr., Bódis Beáta dr., Csécsei Gyöngyi dr., Dobó István dr., Domboróczki Zsolt dr., Drenyovszki Zita dr., Fazekas Gyula dr. Filó Andrea dr., Fodor Istpán dr., Fulcz Ágnes dr., Gáll András dr., Gondos Gabriella dr., Hegedüs Judit dr., Hevesi Judit dr., Kádár Csilla dr., Kazi Zsuzsa dr., Késmárki Nóra dr., Kovács Irén dr., Krajnyik Zoltán dr., Marton Zoltán dr., Mibály Éva dr., Móricz István dr., Nádas Judit dr., Pálhegyi Erika dr., Páll István dr., Papp Zsuzsanna dr., Péter József dr., Polocsányi Béla dr., Rakk Erika dr., Sepp Krisztián dr., Szabó Judit dr., Szabó Sándor dr., Szépkúti Sándor dr. Szfárli Enikő dr., Szilágyi Erzsébet dr., Taybani Zoltán dr. Thaisz Erzsébet dr., Tóth Mária dr., Varga Andrea dr., Vass Viktor dr., Vida Klára $d r$. Valamennyiüket köszönet illeti a betegek toborzásáért és a vizsgálatban való közremúködésért.

\section{Irodalom}

Jermendy G. Randomized, controlled clinical trials with observational follow-up extensions for evaluating efficacy of antihyperglycaemic treatment. I. Main results of the studies. [Antihyperglykaemiás kezelés hatékonyságát megítélő randomizált, kontrollált klinikai tanulmányok obszervációs jellegú utánkövetései. I. A vizsgálatok fontosabb eredményei.] Orv Hetil. 2018; 159: 575-582. [Hungarian]

Jermendy G. Randomized, controlled clinical trials with observational follow-up extensions for evaluating efficacy of antihyperglycaemic treatment. II. Features of and lessons from the followup extensions. [Antihyperglykaemiás kezelés hatékonyságát megítélő randomizált, kontrollált klinikai tanulmányok obszervációs jellegú utánkövetései. II. Az utánkövetés sajátosságai és diabetológiai tanulságai.] Orv Hetil. 2018; 159: 615-619. [Hungarian]

[1] Jermendy G. Metabolic memory in diabetes mellitus. [Metabolikus memória diabetes mellitusban.] Magy Belorv Arch. 2008; 61: 361-367. [Hungarian]

[2] Jermendy G. Intensive conservative insulin treatment in patients with type 2 diabetes mellitus. [Intenzív inzulinterápia 2-es típusú diabetesben.] Orv Hetil. 2012; 153: 1487-1493. [Hungarian]

[3] Guidelines of Ministry of Human Resources: Diagnosis of diabetes mellitus, treatment and management of adult patients with diabetes. [EMMI Egészségügyi szakmai irányelv: A diabetes mellitus kórismézéséről, a cukorbetegek antihyperglykaemiás kezeléséről és gondozásáról felnőttkorban.] Diabetol Hung. 2017; 25: 3-77. [Hungarian]

[4] Inzucchi SE, Bergenstal RM, Buse JB, et al. Management of hyperglycemia in type 2 diabetes, 2015: a patient-centered approach: update to a position statement of the American Diabetes Association and the European Association for the Study of Diabetes. Diabetes Care 2015; 38: 140-149.

[5] Saydah SH, Fradkin J, Cowie CC. Poor control of risk factors for vascular disease among adults with previously diagnosed diabetes. JAMA 2004; 291: 335-342.

[6] ORIGIN Trial Investigators. Characteristics associated with maintenance of mean $\mathrm{AlC}<6.5 \%$ in people with dysglycemia in the ORIGIN trial. Diabetes Care 2013; 36: 2915-2922.

[7] Mauricio D, Meneghini L, Seufert J, et al. Glycaemic control and hypoglycaemia burden in patients with type 2 diabetes initiating basal insulin in Europe and the USA. Diabetes Obes Metab. 2017; 19: 1155-1164.

[8] Hasslacher C, Lorenzo Bermejo J. Treatment with insulin ana$\operatorname{logs}$ and prevalence of cardiovascular complications in patients with type 1 diabetes. Ther Adv Endocrinol Metab. 2017; 8: 149-157.

[9] Cammarota S, Bruzzese D, Catapano AL, et al. Lower incidence of macrovascular complications in patients on insulin glargine versus those on basal human insulins: a population-based cohort study in Italy. Nutr Metab Cardiovasc Dis. 2014; 24: 10-17.

[10] Cammarota S, Falconio LM, Bruzzese D, et al. Lower rate of cardiovascular complications in patients on bolus insulin analogues: a retrospective population-based cohort study. PLoS ONE 2013; 8: e79762.

[11] Rosenstock J, Schwartz SL, Clark CM Jr, et al. Basal insulin therapy in type 2 diabetes: 28 -week comparison of insulin glargine (HOE 901) and NPH insulin. Diabetes Care 2001; 24: 631636.

[12] Kennedy L, Herman WH, Strange P, et al. Impact of active versus usual algorithmic titration of basal insulin and point-of-care versus laboratory measurement of $\mathrm{HbA}_{\mathrm{lc}}$ on glycemic control in patients with type 2 diabetes: the Glycemic Optimization with Algorithms and Labs at Point of Care (GOAL AlC) trial. Diabetes Care 2006; 29: 1-8.

[13] Dailey G, Aurand L, Garg S. Duration of diabetes and hypoglycaemia rates in type 2 diabetes patients treated with insulin glargine vs NPH insulin. Diabetologia 2011; 54(Suppl 1): S262.

[14] Garg SK, Aurand LA, Rimler MS, et al. Diabetes duration and the efficacy and safety of insulin glargine versus comparator treatment in patients with type 2 diabetes mellitus. Endocr Pract. 2014; 20: 120-128.

[15] Mullins P, Sharplin P, Yki-Jarvinen H, et al. Negative binomial meta-regression analysis of combined glycosylated hemoglobin and hypoglycemia outcomes across eleven Phase III and IV studies of insulin glargine compared with neutral protamine Hagedorn insulin in type 1 and type 2 diabetes mellitus. Clin Ther. 2007; 29: 1607-1619.

[16] National Health Insurance Fund. Drug reimbursement rules for patient groups, indications and practitioners. January 1, 2014. [Országos Egészségbiztosítási Pénztár. Az emelt, kiemelt indikációhoz kötött támogatási kategóriába tartozó betegségcsoportok, indikációs területek és a felírásra jogosultak köre]. Available from: www.oep.hu/gyogyszer [accessed: February 20, 2014]. [Hungarian]

[17] Jermendy Gy. The effects of Ministry decrees regulating reimbursement changes of insulin analogues on the sales of insulin products in Hungary in 2012-2013. [Az inzulinanalógok támogatás-módosítását szabályozó minisztériumi rendeletek hatása az inzulinkészítmények forgalmára 2012-2013-ban Magyarországon.] Diabetol Hung. 2014; 22: 187-198. [Hungarian]

[18] Jermendy Gy, LEONCET2 Trial Investigators. Switching from human basal insulin to once daily insulin detemir in type 2 diabetic patients treated by basal-bolus regimen - results from the LEONCET2, an observational, prospective, multicenter study. [Áttérés humán bázisinzulinról napjában egyszer adott detemir inzulinra bázis-bolus rendszerú inzulinterápiával kezelt 2-es típusú cukorbetegek körében. A LEONCET2 többcentrumos, megfigyeléses, követéses vizsgálat eredményei.] LAM 2010; 20: 113-119. [Hungarian]

(Kovács Gábor dr., Budapest, Madarász V. u. 13., 1. ép. 5. em. 85., 1131 e-mail: kovacsgabordr@gmail.com) 